\title{
Misconceptions Underplay Western Ways of Musicking: A Hermeneutic Investigation
}

\author{
Eve E. Ruddock \\ University of Western Australia, Perth, Western Australia
}

This paper draws on a hermeneutic project to reflect on culturally developed notions that distance individuals from their intrinsic musicality. Participant experience offers insight into misconceptions of human musicality in Western communities where unrecognised cultural directives label musical beings as either musical or non-musical. Embedded in language, cultural influences restrict free musicking such that everyday practices inhibit the development of musical skills and dictate life-long inhibition. I argue that to ignore this phenomenon is to perpetuate an unnecessary and harmful reduction of human being.

Keywords: Musicality, enculturation, dialectic insights, hermeneutics, performativity

I don't sing, play music... Something stops me

(Participant $R M$ )

s a species, humans are both biologically and culturally musical (Morri-
son and Demorest 2009), yet many individuals in Western cultures live
with a deep conviction that they are "musically inadequate" (BodkinAllen 2009, 256). This perception is widespread despite evolution of human architecture now showing an adaptation for music processing (Norman-Haignere et al. 2015) - a discovery that supports an understanding of the communicative role that music can play (Malloch et al. 2009). For Malloch and Trevarthan (2009), "musicality" epitomises movement back and forth between people to bring connectivity to their separate lives (9) as it plays towards wordless connection. While

(C) Eve E. Ruddock 2017. The content of this article is the sole responsibility of the author. The ACT Journal and the Mayday Group are not liable for any legal actions that may arise involving the article's content, including, but not limited to, copyright infringement. 
many recognise musicality as being part of our "primordial being" (for example, van der Schyff 2013), two of the protagonists in this paper categorise themselves as being non-musical.

Ever since Blacking (1976) so eloquently brought to light the phenomenon of culturally 'engineered' non-musicality, theorists (Small 1998) and researchers (Swain and Bodkin-Allen 2014; Lines 2003) have further explored this 'unnatural' aspect of Western culture. Despite the seminal writing of Blacking (1976) and Small $(1977 / 1996 ; 1987 / 1998 ; 1998)$ and insightful work from professional musicians (Westney 2003; Paton 2011) and neuroscientists (Levitin 2006; Morrison and Demorest 2009), musical 'disabling' continues. One experienced music educator went so far as to report: "it is not uncommon for individuals to hold negative perceptions of their own musicality as a result of interaction with members of our [the music teaching] profession" [personal communication].

It is important to challenge the view that individuals are musical only if they have developed performance skills-if they can sing or play an instrument. Such widespread assumptions are not only present in everyday culture (Ruddock 2007) but Gracyk (2004) argues that they are also found in the world of research. He contends that a particular research tool (in this case, a survey) led to a slanted view to infer a binary separation between those who learned a musical instrument and those who did not, leading children to label themselves as "nonmusicians" (3). In his article on musical identities, Gracyk (2004) expresses his concern about presuppositions that categorised individuals as musicians or nonmusicians depending upon whether they had music lessons or played instruments. Such unfortunate labelling, Gracyk suggests, can lead children to see themselves as being non-musical when they may not have previously viewed themselves in such a way. It is relevant to wonder how it can be that music education researchers might, unintentionally, contribute to everyday dichotomous assumptions where musical beings are labelled as being either musical or nonmusical. Music educators, too, have been responsible for leading students to believe that they are not musical (Ruddock 2007).

However, before judging teachers and educational researchers as perpetrators of this phenomenon, it is helpful (once again) to heed the voice of Small (1977/1996). He recognised that members of the teaching profession, like their students, are caught within what Straume (2015) terms a "social-historical" reali- 
ty (1468). Thus, prejudice within Western culture itself (Gadamer 1975/2004) acts to distance us from our instinctive musicality (Ruddock 2016) - we fail to notice historically developed misunderstandings of human nature which blind us to inherited dichotomous beliefs that disallow humanning (Nzewi 2013, 4) instinctive action. In this paper, dialectics between participant experience, researcher, and the literature work together to tease out societal directives that undermine a freedom to engage in healthy musicking.

\section{A Hermeneutic Exploration}

"Hermeneutics," Ezzy (2002) explains, "is the art and science of interpretation" (24). So, it is through the elusive, never ending "process" (Ezzy 2002, 77) of interpreting qualitative data in the light of current understandings that this study seeks to recognise assumptions that play against inclusive musicking. Together with a cohort of 12 participants comprising both self-perceived musicians and non-musician participants, selected via 'purposive sampling' (Punch 1998, 193), I began to further tease out questions raised by the 'never picked'1 participants in my previous study (Ruddock 2007). Although I prepared an Interview Guide to ensure that participant communications could access essential information to enhance meaning (Polkinghorne 2005, 142), research conversations were effectively unstructured as I followed up on participants' responses to gain insight into nuances that led to deeper reflections of their reported experiences. I wondered about the something in the epigraph above: What could it be, for example, that stops the research participant, $\mathrm{RM}^{2}$, from singing or dancing? He would not even contemplate singing 'Happy Birthday'! With his first detailed email communication following ethical approval, RM offered fresh perceptions into living with an assumed non-musical position.

Drawing from dialectic interactions of three participants and the literature, this paper explores diverse understandings of human musicality. Two of the participants, RM and Mel, responded to an invitation to be part of the 12 cohorts of my project which developed around a central question: How can everyday musicking be freed from socially evolved constructs that restrict instinctive musical expression? The third, Harry, a central protagonist of my 'never picked' MA study (Ruddock 2007), became involved with this 'misconception' project as a reader of my published papers. Remaining consistent in his views for more than a 
decade, Harry is an articulate representative of those who hold the widespread 'Western' belief that "music is something people could only do if they happened to be born 'musical". His view accurately reflects Levitin's summation that, "in our own culture [we have formed] separate classes of music performers and music listeners (Levitin 2006, 6).

As Ezzy (2002) understands, it is in the nature of hermeneutic analysis itself that the interpretative process continues to play back and forth between participants, researcher, and the literature. Furthermore, Eisner (1998) points to the need to adapt research plans in response to questions arising from lived experience (172). In an initial analysis of data in this investigation of self-perceived musician and non-musician participants, it became clear that not only self-perceived non-musicians suffered from the pervasive effects of ill-timed critical judgement, some musician participants were also silenced (Ruddock 2010). Where Westney (2003) describes such experiences as "performance [associated with] public scrutiny and critical judgement" (138) and Vestad (2014) refers to "the everybodycan narrative and the only-the-talented-can narrative" (266), Kafka (1924/2007) leads us to question the dominance of the notion of unique giftedness that can impose non-musicality to reduce vital humanity.

\section{Mel}

Also questioning this view, participant $\mathrm{Mel}$ enriched the understandings developed in this article. Her personal experience had led her to "feel tone deaf and completely unmusical" so she had determined that her daughters' school should include a comprehensive music curriculum, even when this meant that the family needed to move from their home into a different school catchment area because their original position was near a school that lacked a music program. This social worker and mother of two argued that:

To label individuals as 'unmusical' defines people for a lifetime and stops them participating. I LOVE music, I love listening and singing to music (but always by myself!). I have always felt that I am not good at music and that I am unmusical. I do not know why I cannot recall anyone ever telling me that I am not good at music or am particularly tuneless yet for my whole life even as a child I have defined myself as not good at music. I joined choirs at school but always felt I had no right to be there and that I had snuck in. I would always sing very quietly in

Ruddock, Eve E. 2017. Misconceptions underplay Western ways of musicking: A hermeneutic investigation. Action, Criticism, and Theory for Music Education 16 (2): 39-64. doi:10.22176/act16.2.39 
case my out of tune voice was detected. I would be devastated if my daughters ever perceived of themselves in this way musically.

\section{Understandings of human musicality: RM and Harry}

We may wish to go beyond Plato's (1997) view where "we human beings have been made sensitive to ... rhythm and harmony and can enjoy them" (Laws II 653). Free from the Western domination of talent, performativity and "critical judgement" (Westney 2003, 138), notions that so often determine who will engage with music in the West, Nzewi (2003) speaks from a different perspective. Growing up within the traditions of Nigeria, musicking was an intrinsic part of human being, "a humanizer" (Nzewi 2009, 107). Nzewi demonstrates interconnective, participatory musicking that enables healthy human living where music, like "breath" $(2003,221)$ is a living part of human being. Such embodied knowing would accord with the Oxford English Dictionary (OED) definitions of musicality where the "quality or character of being musical; accomplishment or aptitude in music; musical sensibility" all refer to those myriad aspects associated with the doing of music; these include composing, playing, singing, listening, dancing and all actions associated with music (OED Online 2013). For Nzewi (2002), then, music is more than mere playing and listening; music, for him, "is the science of being, the art of living with health" (paragraph 5). This view is increasingly supported by contemporary neuroscience. Morrison and Demorest (2009), for instance, emphasise the ubiquity of music within cultures and reveal how "cultural constraints on music perception and cognition" are measurable. For many Western individuals, constraints mean life-long separation from a freedom to be musical. A New Zealand study, for example, shows how early childhood teachers from a Western background felt that they could not sing with their students, whereas Maori and Samoan teachers were musically confident (Bodkin-Allen, 2009). Participant RM (part of my hermeneutic study) told how he learned to know that he was not musical:

As a child, I learned that other people do music. It was clear to me and others that I had no ability at all. In the final year at Primary School, we were expected to play recorders as a class. I wiggled my fingers but did not blow, no-one found out. The same applied in communal singing, all that was needed was to open my mouth roughly in concert with the words, no-one knew. More importantly, noone heard anything horrid [researcher italics]!

Ruddock, Eve E. 2017. Misconceptions underplay Western ways of musicking: A hermeneutic investigation. Action, Criticism, and Theory for Music Education 16 (2): 39-64. doi:10.22176/act16.2.39 
I remember very little of what I learnt specifically at school, much of school based learning sinks unnoticed into one's being, but I remember studying Shakespeare's A Midsummer Night Dream in which are some simple people unschooled in the finer arts. They are called the Rude Mechanicals. Later in life when I had learned the lowly position of Engineers [my profession] in a class ridden society, I chose to refer to myself as a Rude Mechanical as a jibe at educational snobs who assume they are the font of all learning... It is both comical and deadly serious, it masks a fair degree of anger at those who think the Classics are intellectual and Engineering is for the plebs. Although I appreciate music of many diverse kinds, I am fully confident that my ability to make music is at or very near zero. When asked to sing, I never comply, the inhibition built up over a lifetime is far too strong as is my certainty that I will never be able to sing. This does not bother me too much, other people make music [researcher italics].

With this final sentence, RM entirely re-captures Harry's view on this aspect of encultured Western practice. RM and Harry, both self-perceived non-musical individuals, offered unique perspectives from which to explore everyday musicking. On the one hand, there was RM, a retired engineer with a deep interest in history and culture who lives in London; he volunteers in various capacities relating to web design and engages in other projects such as military history. Following his acceptance of my invitation to be part of this research, his contribution to my project proved vital. On the other hand, since his retirement, Harry, an educational philosopher participant, continues to edit and write contributions for philosophical research and educational journals; I particularly appreciated his decision to contribute to the dialectic interchange because his view of musicking represents a way of thinking that continues to significantly diverge from the position I have come to hold.

Except for their mutual appreciation of the work of professional musicians, hermeneutic analyses revealed how Harry and RM represent deeply contrasting views on human musicality. As Gadamer (1975/2004) plays with the importance of "sense" as it implies "direction" (356) in the process towards hermeneutic understanding, so too, during the dialectic interaction with Harry and RM, I experienced many moments of unknowing, moments where my musical sensing and knowing dissipated. Rather than being detrimental to my sense of being musical, however, these experiences have, instead, led to a deep change in my sense of what being musical might mean. Like many of the conversational partners of my research, I have undergone a radical change in my understanding of what musi-

Ruddock, Eve E. 2017. Misconceptions underplay Western ways of musicking: A hermeneutic investigation. Action, Criticism, and Theory for Music Education 16 (2): 39-64. doi:10.22176/act16.2.39 
cality is. For example, RM, particularly influenced by current brain research that indicated our "innate capacity" (Levitin 2006, 27) to learn music, wrote that he had become:

convinced ... of inherent musicality. As one of the 'never picked'3, I had considered musical as being good at music, being able to sing or play an instrument, but you have made your case.

These words do not mean that he was persuaded that he might be musical, however, and he made his position clear in his response to the following excerpt from a participant in the 'never picked' study:

20-year-old participant:

By about age 8, I knew I was not musical...this knowing was a gradual thing. I cannot say how it happened. I hardly outshone...others in the class when we learned the recorder...whereas I excelled easily in maths ('never picked' participant, Ruddock 2007, 108-9).

Upon reading the 20-year-old participant's words, RM responded:

Carbon copy of my experiences.

The kids from musical families did and were applauded; they had it, that mystical ability to do music. I didn't or at least thought so.

Am I one of the 'never picked'? Oh yes, I don't sew, paint, sculpt, sing, play music, write (much) poetry, act or take part in politics, all excellent things to do. Something stops me. It is this something that lies at the heart of my project.

\section{Seeing beyond the 'seen'}

So integrated with the fabric of everyday being, contradictions within participant experience that revealed unrecognised cultural influences went unnoticed until it was teased into the open via dialectics. As Foucault warns, influences remain beneath consciousness (Foucault 1972, 15) to direct how life can be. In the beginning, it seemed that assumptions revealed in the text, having developed beneath the surface of awareness over time were "of too magical a kind to be very amenable to analysis" (Foucault 1972, 24). Instead, they led to hermeneutic wondering where "[t]he being that is concerned with its being presents itself, through its understanding of being, as a means of access to the question of being" (Gadamer 1975/2004, 522-3). Thus, it was through complex and contradictory participant

Ruddock, Eve E. 2017. Misconceptions underplay Western ways of musicking: A hermeneutic investigation. Action, Criticism, and Theory for Music Education 16 (2): 39-64. doi:10.22176/act16.2.39 
experience that dialectical interactions toward meaning took place. Together with research data drawn from honest and direct participant contributions, Harry, and the literature, I began to move closer to an understanding of the enigmatic essence of being musical. This process to understanding the phenomenon of culturally imposed non-musicality became clearer when, despite being made aware of findings in contemporary neuroscience that confirmed musicality as an inherent aspect of the human condition, participant Harry maintained a separatist non-musical position. He was aware that research revealed that everyone is capable of being part of their culture's musicking (Koelsch et al. 2000; Levitin 2006, 27)-the only exceptions being those who are born with a neurological malfunction (Nzewi 2009, 188).

Perceptions of non-musicality remained deeply embedded in some participant belief systems. In Harry's case, for instance, the belief that individuals are either born musical or they are not stayed secure, despite the clash with increasing evidence which indicates that all humans are inherently musical (van der Schyff 2013). Through his consistent assertions that humans are either musical or non-musical, Harry leaves little doubt that he is not sympathetic with any notion of universal human musicality. His belief confirms Levitin's (2006) lament where, in Anglo-American cultures, we have learned to "separate classes of music performers and music listeners" (6). In an attempt to make his position clear, Harry devised a list; one which would, in his view, properly clarify what might be meant by the "non-musical classes" (the 'class' to which, in his eyes, he belonged). Here, he assumed that some individuals tended to class themselves as "'musical' while others saw themselves as 'non-musical" and that they proceeded to live with the consequences of such labelling. Thus, with serious pedagogical intent (despite its humorous twist), Harry delivered a way of seeing my project through a perspective of the "non-musical classes".

A careful examination of 'Harry's List' offers a keen insight into the selfperceived non-musical mind.

Non-musical classes

1. Cannot distinguish between noise and music

2. Can distinguish but not moved or interested

3. Moved/interested but not willing to make the effort to listen

4. Willing to listen but not perform 4a. Lack technique/instrument

Ruddock, Eve E. 2017. Misconceptions underplay Western ways of musicking: A hermeneutic investigation. Action, Criticism, and Theory for Music Education 16 (2): 39-64. doi:10.22176/act16.2.39 
4b. Lack confidence

4c. Unwilling to make effort

4d. Unwilling to inflict unsatisfactory performance on self or others

4e. Do not obtain joy from own performance

4f. Others' diagnoses (tone deaf, etc) that exclude from public performance

5. Listening as part of life but not perform

5 a to $5^{f}$

6. Listening as part of life and perform but only as a result of great effort and with unsatisfying or poor results, i.e., not talented so not musical

You can elaborate on (sharpen) these classes if you see fit in the light of your deep understanding of music etc.

I assume you judge a person's life to be flat if they do not engage in music.

4a/f (obviously the scale needs a g) are not mutually exclusive as I expect you are interested in how $\mathrm{f}$ produces $\mathrm{b}, \mathrm{c}, \mathrm{d}$, e. But a to e could be the result of something other than f. Clearly, you can also have harmonics where an individual has more than one of $4 \mathrm{a} / \mathrm{f}$ at the same time.

Harry's List offers a view coloured with assumptions of what music is-a selfperceived non-musical individual might well find their beliefs echoed in this list. While the first point is not relevant to the discussion because this investigation does not consider individuals suffering from a neurological disorder, the remaining claims confirm the excluding influence of the notions of critical performance, judgement, and talent (Ruddock 2012). Bodkin $(2004,16)$ presents evidence to confirm Small's theory (1998) that such cultural assumptions affect many individuals' belief in their ability to engage in musicking, leaving many to learn that, like Harry, they are "non-musical." These assumptions open the way for the talented to be the star performers while many too readily take on the role of the "musically inferior" (Bodkin 2004, 256). Blacking's (1976) question continues to challenge our Western way: "Must the majority be made unmusical so that a chosen few may become more musical?” (4).

On reading points $4 \mathrm{a} / \mathrm{f}$ with Harry's rich data in mind, it is clear that his view of music as excellent performance, something developed through hard work that is not always pleasurable, is far from being a communicative action which enhances connective living (Malloch and Trevarthan 2009). Harry continued to perceive music as something performed, something relying upon talent-something that only some of us have. Again, it was Small (1998) who effec-

Ruddock, Eve E. 2017. Misconceptions underplay Western ways of musicking: A hermeneutic investigation. Action, Criticism, and Theory for Music Education 16 (2): 39-64. doi:10.22176/act16.2.39 
tively challenged this notion of music as object (2); his influential revival of the term musicking (1987/1998, 50) to indicate the action of engaging in singing, dancing or other musical acts, works toward inclusion. As Nzewi (2012) understands, for instance, Africans' inherent musicality is developed through everyday cultural practice; individuals are not automatically musically able-humans develop their musicality within cultural practice. This experiential knowing challenges Harry's perception that being musical "is a thing one is or one isn't"; further, it was this belief that led Welch (2001) to declare that such "limiting conception of humankind as either musical or non-musical is untenable" (22). Whether Harry's List might provoke or entertain, it does raise an important question: How is it that, despite research confirming human musicality (Peretz 2005) and a close interconnection between music and culture (Morrison and Demorest 2009), a pervasive Western cultural practice continues to underplay intrinsic musicality?

In light of societal behaviours that undermine individuals' free engagement in musicking (Joyce 2003; West 2009) Harry's List reminds us how important it is to question societal assumptions that discourage healthy, intrinsic human behaviour. In his interviews, Harry showed that his "pragmatic acceptance was linked to a conviction that, with limited funding, it was mandatory to give priority to 'the important stuff, language, maths, science and social science' in the school curriculum. [He was] convinced that 'language learning, maths and getting a job [were] more worthy of effort (given limited resources) than aesthetic activity (including music)"' (Ruddock 2007, 145).

To consider Harry's claim that music is "a side piece to the whole educational business ... just one of the frills ... an add on ... not essential for the younger child's development" (Ruddock 2007, 104) is to realise how far such thinking is from a wider recognition of universal musicality (Tramo 2001), along with its humanising capacity (Trendwith 2003). As Turino (2008) recognises, the arts are a way of being that can access and express subconscious awareness when communicating with others. Furthermore, Boyce-Tillman (2000) understands that, through our engagement with the arts, we "adults can play ... free to explore [our] own subconscious, and also to make mistakes. They are, therefore, important arenas of self-development" (91). Considering Harry's conception in the light of such views suggests that, because he lacked an essential experience with musical investigation. Action, Criticism, and Theory for Music Education 16 (2): 39-64. doi:10.22176/act16.2.39 
arts in his formative cultural development, he did not have an opportunity to learn to properly appreciate the value of the arts. It is no surprise that his experience affects his lack of support for the arts as an essential component of the school curriculum - a reality exacerbated by his witnessing of inappropriate classroom music teaching.

\section{Performativity $v$ recognition of what is}

It may be that "it is in the performance and only in it ... that we encounter the work itself" (Gadamer 1975/2004, 115). However, connections made available to us when part of a performance, whether as player or audience, can be disrupted when performance turns into performativity when human 'play' turns into a critically judged 'thing'. Gadamer insisted that it is crucial to perceive the essential part the audience plays and that listeners are no mere consumers of the work made by the 'talented' - they are an integral part of the play where, in and through time, they engage with and become part of an event to connect and gain insights into their life-world (110-25). Yet, human connection is threatened by the widespread notion of performativity. And, as Koopman (2005) theorised, "the dominance of performativity threatens to marginalize music and music education" (119); Small (1998) already understood that untoward focus on the success of a performance could damage "the real musical development of ... students" (212).

Thibeault (2010) offers a poignant example of the mistaken value of excellent performance. It occurred at that time of the year when the music teacher had to present a successful concert for parents and senior education officials. Thibeault abandoned his carefully planned healthy music education program (from which all children benefited through understanding and developing their musical voice) to focus on a single-minded practice for an end of semester concert. Finely honed music education aspirations were sacrificed. The performances were splendid! Yet, it was in that very moment when he was receiving accolades for the wonderful result when Thibeault realised something was wrong. He recognised that such vainglorious attempts to look and sound good actually denied young students an opportunity to gain a broad musical understanding and to enjoy their experience. He recognised that, despite the connection between a good musical education 
and an enjoyable performance, "the links between concerts and education are often tenuous" (Thibeault 2010, 27).

Even a minimal music education, however, can have negative effects: during her limited musical education in Scotland, participant Mel had 'learned' to feel "unmusical". Her experience left her determined that such a situation would not happen for her children. When reading several of my published papers, she recognised her own story and agreed to become a participant in my study. During this process, she came to believe that she was musical, reporting that: "I would now describe myself as someone who is musical but I have allowed society to make me perceive myself as unmusical." Indeed, it was her passionate defence of instinctive musicality that led her to oppose Harry's annotations on one of my published papers in an online interaction-Harry noted prejudice in my text. His accusation revealed a "tension between the text" (Gadamer 1975/2004, 305) and my developing hermeneutic perception when he interpreted my meaning through his particular Western tinged lens to reveal a previously unrecognised worldview. In my paper (2012), I had asked: "How is it, then, that within our educational and social institutions we continue to condone a situation where musical beings 'learn' to restrain their intrinsic musicality? Why might they feel the need to accept a role as consumers of others' musicking?" (219) Harry underlined my final phrase and annotated: "Now you are being disparaging and revealing your deep prejudice instead of rejoicing at their participation as essential members of the musical community."

Deep prejudice? Wondering about this accusation, I re-examined interview and annotation texts. Further interpretation was required. It was important to tease out Harry's references to "essential members of the musical community" together with his belief that being "musical...was a thing one is or one isn't." Regarding his young grandchildren's musicality, for instance, he had commented:

I wouldn't think of them as 'mathematical' or 'musical' etc., but if [they] did something which showed that they were talented or appreciative-they mean two different things-then I would say, 'yes, [they are] 'mathematically' talented or appreciative or 'musically' talented or appreciative ... to be 'musical' could be 'appreciative' or 'talented' (reported in Ruddock 2007, 126).

Harry's world is one shared by many in Western culture. Those judged to be musical are split into two major groups: the talented - the singers and players, and 
the appreciative - those who understand, enjoy listening and/or collecting music. Further, some individuals were perceived as being musical because of their superior knowledge about music; Harry's view edged toward this conception. Davidson (1994) understands the negative effects of such separatist notions where the domination of the "talent account" (Howe et al. 1998) "isolates later development from early experience. The continuity of growth is cut off. Early forms of musical knowing are ignored in favor of the formal, articulated knowledge of the expert" (Davidson 1994, 102). Davidson's (1994) research indicates that this predominance of the importance of talent leaves individuals with a skewed view of the vibrant reality of music in their everyday lives. He understands that such limitations of human expression are an outcome of educators' and musicians' limited perceptions of music awareness.

Harry's challenge, then, raises many issues. In accusing me of prejudice, he subtly uncovered his self-perceived position, which, as mentioned above, he shares with many people in our society. From his viewpoint, Harry did not heed references in my work that supported inherent musicality; he insisted that my argument required individuals to demonstrate developed ability to sing or play if they were to be considered 'musical'. His following comments further clarified his position:

I think conceptual clarity is useful. Indicating terms to designate the talented, the background range of musicness and the totally absent (but still human) would help. Your definition of 'unmusical', 'not musical' will need to make clear how some attitudes, values, personality characteristics, whatever, lead a person to choose not to do what you value for reasons of your own.

I cannot see how anyone could learn an instrument without considerable practice well above and beyond what is enjoyable in itself. Constant [playing of] scales IS NOT INHERENT or ENJOYABLE [Harry's capitals].

This final comment incensed one community reader who wrote: "Harry seems to equate being musical with the ability to perform. Practising to be beyond enjoyable! How does he think musical people become proficient? AND some people ... actually enjoy scales!"

In revisiting early conversations with Harry, I further recognised their potential to lead to deeper insights into how we speak about human musical nature.

Harry But lots of people say ... would say 'you're not physical or you're not mechanical not mathematical or not musical...

Ruddock, Eve E. 2017. Misconceptions underplay Western ways of musicking: A hermeneutic investigation. Action, Criticism, and Theory for Music Education 16 (2): 39-64. doi:10.22176/act16.2.39 
Eve So you see it in the same sense?

Harry Yes ... not naturally inclined that way or whatever...

Eve But not denying that it's an intrinsic part ... an integral part still of their lives [i.e. being musical] ... like it is for you...?

Harry Oh, I'm musical in other senses. But that's not the way in which that sort of use of that term is focussed.

These comments complement email communications a decade later in which, attempting to tease out this notion of being 'musical in other senses', Harry suggested that ' $[\mathrm{t}]$ he focus could then shift from how to do to how we may enjoy'. Despite being defensive when he perceived (incorrectly from my perspective) that I had underestimated the importance of his music listening, he failed to consistently recognise the 'essential' part that he played in his own sensual experiencing. He steadfastly maintained a separatist view regarding music; he knew that he could not do music. He held on to this position despite the fact that he enjoyed listening to his favourite recordings and that his carefully chosen listening demonstrated that he was an integral part of the musical community. As a discerning listener, he was not merely a "receiver of" music (his original claim), but was a critical part of the whole, completing the part played by the musicians (de Haan 1998)4.

Gadamer (1975/2004) also understands how players play their part so that the whole can be experienced (108) and Westney (2003) offers an example of such connective experiencing. During a piano recital, he sensed "the collective awareness, the attentive mind of the audience" (148) wherein he experienced a palpable link between himself and the listeners as they came together as a musicking community. This mutually connective example highlights the separatist aspect of Harry's "performer v receiver" view which contradicts his experience that " $[\mathrm{t}]$ he response of the spectator also feeds back into the performance so it is not a one-way relation." In response to my words noting participants feeling "that they have no 'licence' to do music and that they are not part of the human musical community" (Ruddock 2012, 207), Harry noted that he aligned "with the former but not the latter." I wondered: had he not questioned how his teenage attempt to learn the trumpet was undermined by his tutor's lack of insight and skill? Had he not considered effects of the lack of musical environmental learning in his childinvestigation. Action, Criticism, and Theory for Music Education 16 (2): 39-64. doi:10.22176/act16.2.39 
hood, where his only musical 'education' was to sing along to the $\mathrm{ABC} 5$ weekly broadcast to schools on the radio?

\section{Mel and Harry}

Mel strongly disagreed with the stance taken by Harry; her opposition triggered an interchange that delivered an important insight on musicking. Harry perceived music as a production by the talented wherein non-musicians, as 'spectators', are 'receivers of' the music whereas Mel understood music and the doing of music to be instinctive aspects of being human. She knew that humming along to others' musicking or "when you sing inside and yet make no noise" placed a person in the role of musicker. In Harry's view, his separatist notion perceived the musician and the spectator playing the parts of performer and listener, while Mel accepted that humans are being musical as they become involved in a musical event. In pedagogical mode, as part of our dialogues, Harry considers these positions:

Spectators are no 'mere' item. To be a spectator (a form of receiver) is to be wired for sound in a particular way that produces a form of satisfaction in the spectator. Some of that wiring is (according to you) hard and some of it is learned. The response of the spectator also feeds back into the performance so it is not a one-way relation. So, the 'separatist view' accepts the other view on its own level but its focus is on the macro-role of the individual (as performer or spectator)-both are musical but the spectator is a non-musician and may be unmusical. I suspect that the issue here is one of differing 'levels of description' as with 'You are just a blob of water with some other chemical reactions tossed in' or 'You are a sensitive, talented musician destined to make much of the world happy'.

Could his reading of philosophy and awareness of tradition, be influencing Harry's response? A Western traditional view of musicality, with its roots coming from the time when the Romans adopted Greek thinking, places an emphasis on excellence; persons with good taste show proper judgement and so would play or sing only if their playing were superior. Tellingly, a participant of a study exploring societal influences affecting a freedom to sing (Whidden, in Ruddock 2012) believed that "Our culture keeps everyone in check" (208). Harry might agree. He noted that: "to sing. i.e. to be musical is to perform"; for a non-musical person like him, it would not be in good taste to sing.

Ruddock, Eve E. 2017. Misconceptions underplay Western ways of musicking: A hermeneutic investigation. Action, Criticism, and Theory for Music Education 16 (2): 39-64. doi:10.22176/act16.2.39 
Unlike Harry who equated being musical with excellent performance, Mel believed that everyone has music in them. Despite this, however, she had often found herself overwhelmed with self-perceptions that denied this fundamental human attribute:

An 'unmusical person' in my opinion doesn't exist. However, discriminatory actions leave some individuals feeling as though they are tone deaf. Singing is where music stems from - you can hear yourself sing inside and yet make no noise. My children and I enjoy singing together.

Individuals are not encouraged if [they] don't excel or sound in tune. Music is treated differently from other subjects.

I feel sad for the little girl me-shut away from doing music and felt I had no right to sing.

Her conception of herself as an unmusical person had changed during the time of her involvement with this investigation and through her nurturing of her children. She had developed an ability to engage in communicative musicking; she valued feeling free to be musical-whether listening alone or singing in the car with the children. Her more inclusive understanding of musicking contrasted with that of Harry; she no longer separated performance from participation but recognised the connection-one that invited communication. Through her awareness of how musical skills are learned, Mel understood the misconceptions (including negative self-judgement) experienced when individuals did not have access to developmental music learning. As she said, she "would be devastated if [her] daughters ever perceived of themselves in this way musically".

\section{Guilty as charged!}

In my practice of sending completed papers to interested dialectic partners, I was initially surprised at Harry's accusation of my bias in favour of skilled singers and instrumentalists. A music philosopher, upon reading Harry's criticism, assured me that the paper was not biased in favour of performers. However, when I returned to the text (Ruddock 2008) to seek evidence of the prejudice mentioned above, an even greater surprise occurred. Without the ameliorating surrounding sentences, Harry was right! Especially if the individual were sensitive to feeling excluded, a discerning reader could properly interpret the sections to read that non-performers might not be considered as 'musical'. Without the broader impli- 
cations carried by the intervening text, Harry had correctly identified (unintentional) bias.

Language can be suggestive in "subtle and insidious" (Wierzbicka 2011, 43) ways; we are shaped by our language. Indeed, we can apply Wierzbicka's (2011) questioning of English usage to Harry's reading of my text. If we appreciate music as an intrinsic aspect of our humanity, then we understand that all humans are musical, rare exceptions being only those who suffer from neurological abnormalities. If Harry were to read my text with this knowing, he would not need to accuse me of 'being disparaging and revealing deep prejudice'. But-Harry believes that individuals are either musical (i.e. they can play or sing to a particular standard) or they are not. Reading my text from his perspective means that nonsingers/players are not musical. His accusation raises an important question regarding the reified state of 'music' in our everyday world.

\section{In search of the something}

How can we better recognise the something that arrests human musicking? While evidence from neuroscience research now confirms the instinctive nature of human musicality (Collins 2013) and qualitative research demonstrates it (Ruddock 2012), researchers in the area of musicking do not have to look far to find those who label themselves as non-musical. Although RM and Harry both listen to and respond to particular music, for instance, in their Western culture they define themselves as being non-musical. Both purposively select and enjoy favoured music; yet, succumbing to societal pressures where "musical barriers that are inherited in Western societies by the time children reach 'the age of reason" (Higgins and Shehan Campbell 2010, 1), they do not feel free to acknowledge their inherent musicality. Despite the "musical barriers," their stories show how their musical selves reach out to connect with music in a way that enhances their lives and tends their emotional needs. Not only does their perceptive listening to music reveal the palpable participatory nature of their musicking, but also their willingness to contribute generous time and thought to my project. In her work to expose and eliminate barriers to musicking, West (2009) captured her participants' predicament to reveal how our Western culture suffers a "psychosocial" (215) void. Her concern that singing and playing are necessarily restricted to "gifted" individuals while the rest suffer a "Selective mutism for sing-

Ruddock, Eve E. 2017. Misconceptions underplay Western ways of musicking: A hermeneutic investigation. Action, Criticism, and Theory for Music Education 16 (2): 39-64. doi:10.22176/act16.2.39 
ing" leads her to argue that such societal dysfunctions in singing and music education are reflective of "a general social dysfunction" (215). Through direct interaction with members of the community, her on-going "Outreach Program" (West 2004) offers a way to free people from hidden restrictions that circumvent vibrant music involvement.

RM would qualify for all categories of West's Selective Mutism for Singing (2009); undoubtedly his home and school environments contributed to his view. Yet, much of that mysterious something that led to RM's deep inner knowing related to still unexplained but powerful "dynamic culture-biology interactions" (Chiao 2009b, vii). I posit that Thibeault's (2010) mid-flight recognition of dangers inherent in the polished performance, with its expectations of high standards of presentation, brings us closer to understanding this something. The something, perhaps, considered in Straume's (2015) paper on the philosopher Castoriadis where she considers how important it is to emphasise that human being fails to flourish in a world of reductionist thinking/being (1474). Like Castoriadis (in Straume 2015, 1474), Thibeault (2015) demonstrates the value of imagining. He drew on his teaching experience to expose a tension between music education practice that favoured the production of a polished product and an inclusive music education to show how "[p]articipatory music, built on different values, suggests a viable alternative-music education designed for all” (Thibeault 2015, 59). In his alternative view, no-one would 'learn' that they were nonmusical.

Unfortunately, RM's lived experience supports Thibeault's suspicion of a 'performance-based curriculum' (2010, 27) where only some students shine-at the expense of others' exclusion. In RM's words:

Of all the experiences of my past 60 years, why do I remember so very clearly faking it during a recorder concert at primary school? Whilst the others blew for all they were worth, I merely wiggled my fingers on the recorder without blowing in the full knowledge that I could not move my fingers in concert with my desires. It was a key moment in my non-musical development [emphasis added].

Thibeault $(2010,2015)$ recognised that the widespread focus on 'high stakes' performances could limit potential musical learning opportunities for students which, in worst case scenarios (such as those experienced by many participants in my research), lead individuals to know that they are not musical. 
For many readers, Harry's List might appear to provide a logical and convincing conception of human musicality. However, I argue here that the assumptions beneath his 'rational' list reflect a flawed understanding of what it means to be musical. This list has no acknowledgement of the "implicit musical ability of the human brain" (Koelsch et al. 2000, 539), nor a perception that:

All of us have the innate capacity to learn the linguistic and musical distinctions of whatever culture we are born into, and experience with the music of the culture that shapes our neural pathways so that we ultimately internalize a set of rules common to that musical tradition (Levitin 2006, 27).

Harry fails to recognise societal pressures that can lead individuals to restrict their musical learning and to succumb to that something that distances them from active engagement which could enable the development of musical abilities. Interdisciplinary work (Chiao 2009a) now reveals how the roots of culture lie in neurological processes of our brains which, in turn, are affected by developed cultural practices as in a feedback loop. Harry's 'Non-musical classes' may thus be seen to reflect an imposed social construction. I argue that this conception of music, clearly defended by Harry, is caught up in an elitist perspective, arguably inherited from Greek origins (Straume 2015, 1468), that obfuscates holistic awareness; it reifies music as a form of specialised behaviour, fully accessible only to the initiated. I posit that this view, cleverly caught by an individual finely attuned to expectations imposed by his tradition, fails to appreciate the vital connectivity offered by music in its many and varied forms.

Harry's exposé of music as something that talented individuals do for the non-talented to appreciate is important. On the one hand, this reified and separatist view reflects our restricted Western conviction of music as a performance for critical judgement, rather than properly portraying communicative, connective, human action. It too readily perpetuates a class system where elitism and pride exclude many people from developing their musical voice. A connective musical experience, on the other hand, is one where music happens for both listeners and performers as part of a musical event; one where play connects. The former, a performance for the consumer, creates a limited avenue for the development of the human spirit; whereas the latter, a performance with others as audience, dancers, singers, etc, helps to form community of spirit and to enhance healthy human expression. We can actively 'participate' by listening (Gadamer investigation. Action, Criticism, and Theory for Music Education 16 (2): 39-64. doi:10.22176/act16.2.39 
2004, 108; de Haan 1998); we become part of the musicking as, together with the musicians, we experience the music that brings us to a deeper understanding of ourselves and of our world. Thus, the players play music so that the whole becomes an experience for all who engage in the musicking.

In my attempt to understand this puzzle where cultural influences affect everyday human musicking, hermeneutic approaches continue to refine the essence of what it means to be free to be musical, free to respond to the inherent part of our nature that has existed and has been developed since primordial human beginnings. So often, it is because of the participants' lack of freedom to respond to and develop their musicality that their contributions reveal obstructive societal influences. To imagine musicking not constructed as "a thing" (Small 1998, 2) but as an evolved part of humanity could divert that something that gets between us and our intrinsic musicality. The reified Western view, clearly recognised by Small $(1998,2)$, leads us to separate out inherent, communicative musicking in favour of performance abilities. Doing this research has made it clear that, despite recent understandings that confirm how musical abilities develop within a musical community, we too often remove a nurturing environment and proceed to make the irrational claim that an individual is either musical or not. To insist that music is something made by expert musicians is to fail to acknowledge the crucial part that musicking plays in our everyday lives as we respond and connect through sound, rhythm, and movement. Participant experience suggests that recognition of human musicality per se is what matters and that the splitting of individuals into musical or non-musical is constricting and divisive.

\section{About the Author}

Eve Ruddock taught music at schools in several States of Australia before specialising in private studio teaching. Questions about Western music practice led her to undertake postgraduate research at The University of Western Australia where she has recently completed her PhD.

\section{Acknowledgements}

I am grateful to the 4 anonymous reviewers for their most generous engagement with this paper and thank Vincent Bates for his warm encouragement. 


\section{References}

Blacking, John. 1976. How musical is man? London: Faber \& Faber.

Bodkin-Allen, Sally. 2009. Being musical: Early childhood teachers, music and identity in Aotearoa/New Zealand. Saarbrucken: LAP Lambert Academic Publishing.

Bodkin, Sally. 2004. Being musical: Teachers, music, and identity in early childhood education in Aotearoa/New Zealand. PhD diss., Otago University.

Boyce-Tillman, June. 200o. Promoting well-being through music education. Philosophy of Music Education Review 8 (2): 89-98.

Chiao, Joan Y. 2009a. Cultural neuroscience: A once and future discipline. In Progress in brain research: Cultural neuroscience: Cultural influences on brain function, edited by J. Y. Chiao. New York: Elsevier.

Chiao, Joan Y. 2009b. Preface. In Progress in brain research: Cultural neuroscience: Cultural influences on brain function, edited by Joan Y. Chiao. New York: Elsevier.

Collins, Anita. 2013. Neuroscience meets music education: Exploring the imlications of neural processing models on music education practice. International Journal of Music Education 31 (2):217-31.

Davidson, L. 1994. Songsinging by young and old: A developmental approach to music. In Musical perceptions, edited by R. Aiello and J. A. Sloboda. New York: Oxford University Press.

de Haan, Simone. 1998. The relationship between the composer, performer and listener in twentieth century music-making. The Australian music teacher magazine Sept/Oct: 238-247.

Eisner, Elliot W. 1998. The enlightened eye: Qualitative inquiry and the enhancement of educational practice. Upper Saddle River, NJ, Prentice-Hall.

Ezzy, Douglas. 2002. Qualitative analysis: Practice and innovation. Crows Nest NSW Australia: Allen \& Unwin.

Foucault Michel. 1972. Archaeology of knowledge. London, Routledge.

Gadamer, Hans-Georg. 1975/2004. Truth and method. Translated by J. Weinsheimer and D. G. Marshall. 2nd, Revised Edition ed. London: Continuum. 
Gracyk, Theodore. 2004. Does everyone have a musical identity? Reflections on musical identities. Action, Criticism \& Theory for Music Education 3 (1):121.

Higgins, Lee, and P Shehan Campbell. 2010. Free to be musical: Group improvisation. Lanham: Rowman \& Littlefield Publishers, Inc.

Howe, Michael J.A, Jane W Davidson, and J. A Sloboda. 1998. Innate talents: Reality or myth? Behavioral and Brain Sciences 21 (3): 399-407.

Joyce, Victoria Moon. 2003. The "subject" is singing: Singing as social practice. Paper read at Music and Lifelong Learning Conference and Celebration, 810 May 2003 at Don Wright Faculty of Music, University of Western Ontario' London, Canada.

Kafka, Franz. 1924/2007. Josefine, the Singer or the Mouse People. Translated by M. Hofmann. In Metamorphosis and Other Stories, 264-83). London: Penguin Books.

Koelsch, Stephan, Gunter, Angela D. Friederici, and Erich Schröger. 2000. Brain indices of music processing: "Non-musicians" are musical. Journal of Cognitive Neuroscience 12 (3): 520-41.

Koopman, Constantijn. 2005. Music education, performativity and aestheticization. Educational Philosophy and Theory 37 (1): 119-31.

Levitin, Daniel. 2006. This is your brain on music: Understanding a human obsession. London: Grove Atlantic Ltd. Original edition.

Lines, David. 2003. The melody of the event: Nietzsche, Heidegger and music education as cultural work. PhD diss., University of Auckland, Auckland.

Malloch, Stephen, and Colwyn Trevarthen. 2009. Musicality: Communicating the vitality and interests of life. In S. Malloch \& C. Trevarthen (Eds.), Communicative musicality: Exploring the basis of human companionship, edited by Stephen Malloch and Colwyn Trevarthen, 1-11. Oxford: Oxford University Press.

Morrison, Steven J., and Steven M. Demorest. 2009. Cultural constraints on music perception and cognition. Progress in rain Research 178: 67-77.

Norman-Haignere, Sam, Nancy G. Kanwisher, and Josh H.McDermott. 2015. "Distinct cortical pathways for music and speech revealed by hypothesis-free voxel decomposition.” Neuron 88 (6): 1281-96. 
Nzewi, Meki. 2002. Backcloth to Music and Healing in Traditional African Society. In Voices: A world forum for music therapy.

Nzewi, Meki. 2003. African musicianship in the global thrust: Redemption for disorienting human pulse. In Musicianship in the 21st century: Issues, trends and possibilities, edited by S. Leong. Sydney: Australian Music Centre.

Nzewi, Meki. 2009. Ensemble of merry voices: Nagging public consciousness. In African indigenous knowledge-sensed musical arts education: Policy considerations, edited by M. Masoga, M. Nzewi and O. d. Nzewi, 93- 107. Sommerset West: African Minds.

Nzewi, Meki. 2012. The Igbo Concept of Mother Musicianship. Rozenberg Quarterly.

Nzewi, Meki. 2013. Humanity essence of African musical arts: The soft science of repetition and internal variation patterns. Paper presented at the International Seminar on 'Creating \& Teaching Music Patterns', Department of Instrumental Music, Rabindra Bharati University, December 16-18.

OED Online. Oxford University Press. http://www.oed.com.ezproxy.library.uwa. edu.au/viewdictionaryentry/Entry/124113

Paton, Rod. 2011. Lifemusic: Connecting people to time. Dorset, England: Archive Publishing.

Peretz, Isabelle. 2005. The nature of music. International Journal of Music Education 23 (2):103-105.

Plato. 1997. Laws. Translated by T. J. Saunders. In Plato: Complete works, edited by J. M. Cooper, 1318-1616). Indianapolis: Hackett.

Polkinghorne, Donald E. 2005. Language and meaning: Data collection in qualitative research. Journal of Counseling Psychology 52 (2): 137-45.

Punch, Keith F. 1998. Introduction to social research: Quantitative \& qualitative approaches. London: Sage

Ruddock, Eve E. 2007. Ballad of the 'never picked': A qualitative study of selfperceived non-musicians' perceptions of their musicality. MM thesis, School of Music, University of Western Australia, Perth. 
Ruddock, Eve E. 2008. “It's a bit harsh, isn't it!” Judgemental teaching practice corrupts instinctive musicality. Paper read at Proceedings of the XXXth Annual Conference: Innovation and Tradition: Music Education Research, 3-5 October, at Melbourne, Victoria, Australia.

Ruddock, Eve E. 2010. Societal judgment silences singers. In Unesco observatory, faculty of architecture, building and planning, the University of Melbourne refereed e-journal.

Ruddock, Eve E. 2012. "Sort of in your blood": Inherent musicality survives cultural judgement. Research Studies in Music Education 34 (2): 207-21.

Ruddock, Eve E. 2016. Western prejudice towards intrinsic musicality. In Proceedings of Philosophy of Education Society of Australasia 46th Annual Conference 2016: Knowledge Ecologies, edited by R. Irwin, 181-92). Warwick Hotel, Fiji Islands: Philosophy of Education Society of Australasia (PESA).

Small, Christopher. 1977/1996. Music, society, education. Middletown, CT: Wesleyan University Press.

Small, Christopher. 1987/1998. Music of the common tongue: Survival and celebration in African American Music. 2nd ed. Middletown, CT: Wesleyan University Press.

Small, Christopher. 1998. Musicking:The meanings of performing and listening. In Music/Culture, edited by G. Lipsitz, S. McClary and R. Walser,. Hanover, $\mathrm{NH}$ : Wesleyan University Press.

Straume, Ingerid S. 2015. The Subject and the World: Educational challenges. Educational Philosophy and Theory 47 (13-14): 1465-76.

Swain, Nicola, and Sally Bodkin-Allen. 2014. Can't sing? Won't sing? Aotearoa/New Zealand 'tone-deaf' early childhood teachers' musical beliefs. British Journal of Music Education; An International Journal 31 (3): 245-263

Thibeault, Matthew D. 2010. General music as a cure for the high-stakes concert. General Music Today 23 (3): 27-35

Thibeault, Matthew D. 2015. Music education for all through participatory ensembles. Music Educators Journal.

Tramo, Mark J. 2001. Music of the hemispheres. Science 291: 54-6. 
Trendwith, Scott. 2003. Humanising the music curriculum: Cross-cultural experiences from Northern Australia. In Musicianship in the 21st century: Issues, trends \& possibilities, edited by S. Leong, 317-21). Sydney NSW, Australia: Australian Music Centre.

Turino Thomas. 2008. Music as social life: The politics of participation. Chicago, IL: The University of Chicago Press.

van der Schyff, Dylan. 2013. Music, culture and the evolution of the human mind: Looking beyond dichotomies Hellenic Journal of Music Education, and Culture. Volume 4.

Vestad, Ingeborg Lunde. 2014. Children's subject positions in discourses of music in everyday life: Rethinking conceptions of the child in and for music education. Action, Criticism \& Theory for Music Education 13 (1): 248-78.

Welch, Graham. 2001. The misunderstanding of music [An Inaugural Lecture]. Retrieved 2009, from The Institute of Education. http://www.ioe. ac.uk/schools/ah/misunderstandingtext.pdf.

West, Susan. 2004. Hand-in-Hand. In Music in Communities Network: Music Australia.

West, Susan. 2009. Selective mutism for singing (SMS) and its treatment: Conceptualising musical disengagement as mass social dysfunction. In Musical understanding: Proceedings of the XVII National Conference, edited by W. Baker. Launceston, Australia: Australian Society for Music Education (Tasmanian Chapter).

Westney, William. 2003. The perfect wrong note: Learning to trust your musical self. Pompton Plains, NJ: Amadeus Press.

Wierzbicka, Anna. 2011. Defining 'the humanities'. Culture \& Psychology 17 (1): $31-46$.

\section{Notes}

${ }^{1}$ Never picked: This term is taken from words of a participant in my MA study: The Ballad of the never picked (Ruddock 2007). It refers to those who feel that they are not musical and would never be chosen to sing, dance or play.

${ }^{2}$ Pseudonyms are used for the participants in this paper; RM will tell how his name came to be. 
3 RM was not part of the 'never picked' (Ruddock 2007) cohort. He refers to the fact that he identifies with their non-musical position.

4 De Haan recognises that it is important to "address the issue of listening as an essential and integral part of the music-making process" (238).

5 Australian Broadcasting Commission-Australian Broadcasting Corporation since 1983

Ruddock, Eve E. 2017. Misconceptions underplay Western ways of musicking: A hermeneutic investigation. Action, Criticism, and Theory for Music Education 16 (2): 39-64. doi:10.22176/act16.2.39 